\title{
Ekşi Hamur Fermentasyonu ile Üretilmiş Kek Hamurunun Laktik Asit Bakterileri Çeşitliliği
}

\author{
Merve Kahraman $^{1,2 *}$, Muhammet Arıc1 ${ }^{2}$ \\ ${ }^{1}$ Şölen Çikolata Gıda San. ve Tic. A.Ş., İstanbul, Türkiye (ORCID: 0000-0002-3699-4524) \\ 2 Yıldız Teknik Üniversitesi, Kimya - Metalürji Fakültesi, Gıda Mühendisliği Bölümü, İstanbul, Türkiye (ORCID: 0000-0003-4126-200X)
}

(Illk Geliş Tarihi 15 Mart 2020 ve Kabul Tarihi 23 Mayıs 2020)

(DOI: 10.31590/ejosat.732009)

ATIF/REFERENCE: Kahraman, M., \& Arıcı, M. (2020). Ekşi Hamur Fermentasyonu ile Üretilmiş Kek Hamurunun Laktik Asit Bakterileri Çeşitliliği. Avrupa Bilim ve Teknoloji Dergisi, (19), 32-42.

\begin{abstract}
$\ddot{O} \mathbf{z}$
Bu çalışmada Tip I ekşi hamur ile üretilmiş kek hamurunun laktik asit bakteri (LAB) çeşitliliği belirlenmiş ve izole edilen LAB türlerinin teknolojik özellikleri incelenmiştir. Bu amaçla, $1: 1$ oranında un ve su karıştırılarak $25-27^{\circ} \mathrm{C}^{\prime}$ de, $\% 80-90$ bağıl nemde 24 saat fermentasyona bırakılmıştır. Ekşi hamurun sahip olduğu özellikleri elde edebilmek için fermente hamur tekrar beslenerek fermentasyona bırakılmıştır. \%10, \%15 ve $\% 20$ oranlarında tip I ekşi hamur içeren 3 farklı kek formülasyonu oluşturulmuştur. Tip I ekşi hamur ve formülasyonda yer alan diğer bileşenler karış̧ırılarak elde edilen hamurlar $30-35^{\circ} \mathrm{C}^{\prime}$ de, $\% 80-90$ bağll nemde $4-6$ saat fermentasyona bırakılmıştır. Elde edilen kek hamurlarından 18 laktik asit bakterisi türü izole edilmiştir.16S Ribozomal RNA (rRNA) Polimeraz Zincir Reaksiyonu (PZR-PCR) ile tür tanımlaması yapılmış ve Leuconostoc, Pediococcus ve Lactobacillus cinslerine ait türler tanımlanmıştır. Tanımlanan LAB türlerinin asit üretim yeteneği, farklı $\mathrm{pH}$ değerlerinde gelişme, farklı tuz konsantrasyonlarında gelişme ve Escherichia coli, Salmonella Typhimurium, Bacillus cereus, Staphylococcus aureus'a karşı antibakteriyel aktivitesi belirlenmiştir. İzole edilen LAB türlerinin 24 saat sonunda 0,459-1,089 g/100 mL; 48 saat sonunda 0,585-1,890 g/100 mL laktik asit ürettiği belirlenmiştir. Farklı $\mathrm{pH}$ değerlerinde gelişme yetenekleri incelenen LAB izolatlarının $\mathrm{pH}$ 2'de zayıf gelişme gösterdiği ve Pediococcus cinsi örneklerden bazılarının gelişme göstermediği; $\mathrm{pH}$ 9,6'da bir tane Pediococcus cinsi bakteri hariç diğer LAB türlerinin iyi gelişme gösterdiği tespit edilmiştir. LAB izolatları \%9 tuz konsantrasyonunda en zayıf gelişmeyi gösterirken; \%6 tuz konsantrasyonunda en iyi gelişmeyi Pediococcus cinsi örnekler göstermiştir. LAB izolatları en çok Salmonella Typhimurium'a karşı antibakteriyel etki göstermiştir. En büyük zon çap1 9 mm ile Salmonella Typhimurium’a karşı oluşturulmuştur.
\end{abstract}

Anahtar Kelimeler: Ekşi hamur, kek, laktik asit bakterileri

\section{Biodiversity of Lactic Acid Bacteria in Cake Dough Produced by Sourdough Fermentation}

\begin{abstract}
In this study, the lactic acid bacteria (LAB) variety of cake dough produced with Type I sourdough was determined and the technological properties of the isolated LAB species were investigated. For this purpose, flour and water were mixed in a 1: 1 ratio and fermented at $25-27^{\circ} \mathrm{C}$ with $80-90 \%$ relative humidity for 24 hours. In order to obtain the properties of sourdough, the dough was fed again and left for fermentation. Three different cake formulations were prepared, containing $10 \%$, $15 \%$ and $20 \%$ of type I sourdough. The dough obtained by mixing type I sourdough and the other ingredients in the formulation were left to fermentation at $30-35^{\circ} \mathrm{C}, 80-90 \%$ relative humidity for 4-6 hours. 18 lactic acid bacteria types are isolated from the cake doughs. Species identification was made with 16S Ribosomal RNA (rRNA) Polymerase Chain Reaction (PCR) and Leuconostoc, Pediococcus, Bacillus and Lactobacillus strains were identified. Acid production ability of LAB species, development at different pH values, development at different salt concentrations and antibacterial activity against Escherichia coli, Salmonella Typhimurium, Bacillus cereus, Staphylococcus aureus were determined. It was determined that the isolated LAB species produced 0.459-1.089 $\mathrm{g} / 100 \mathrm{~mL}$ and
\end{abstract}

* Sorumlu Yazar: Yıldız Teknik Üniversitesi, Kimya -Metalürji Fakültesi, Gıda Mühendisliği Bölümü, İstanbul, Türkiye, ORCID: 0000-0002-36994524, merve.kahraman@solen.com.tr 
0.585-1.890 g/100 mL lactic acid after 48 hours. It was determined that LAB isolates, whose growth abilities at different $\mathrm{pH}$ values were examined, grew poorly at $\mathrm{pH} 2$ and some of the Pediococcus species did not grow. It was determined that other LAB species showed good growth except for one Pediococcus isolate at $\mathrm{pH}$ 9.6. LAB isolates showed the least growth at 9\% salt concentration. Samples of the genus Pediococcus showed the best growth at a $6 \%$ salt concentration. The greatest antibacterial activity of the LAB isolates were determined to be on Salmonella Typhimurium. The largest zone diameter of 9 mm was created against Salmonella Typhimurium.

Keywords: Sourdough, cake, lactic acid bacteria

\section{Giriş}

Ekşi hamur; bünyesinde laktik asit bakterileri ve mayaları bulunduran hamur kütlesi olarak tanımlanmaktadır. İçerdiği LAB ve maya sayısı sırası ile 6- 9 log kob / g ve 5- 8 log kob / g arasında değişiklik gösteren ekşi hamurun pH'sı yaklaşık 4 civarındadır (Minervini ve ark., 2013). M.Ö. 1800'lü yıllarda eski Mısır'da, hamurun kendi haline bırakılması ile tesadüfen bulunduğu düşünülmektedir. Çeşitli aşamalardan geçerek ekşi hamur yöntemi olarak günümüze kadar gelmiştir ve mayalama yöntemi olarak kullanılmaktadır (Elgün ve Ertugay, 2002; Çağlıyan, 2008).

Ekşi hamur elde edilme yöntemlerine göre Tip I, Tip II ve Tip III olarak sınıflandırılır. Tip I ekşi hamur geleneksel yöntemlerle üretilen ve günlük besleme gerektiren hamur tipidir. Belli oranlarda un ve suyun kontrollü koşullarda fermentasyona bırakılması ile elde edilir. Fermentasyon genellikle $20-30^{\circ} \mathrm{C}$ (oda sıcaklığı) aralığında gerçekleşir (Chavan ve Chavan, 2011; Meroth ve ark., 2003; Garofalo ve ark., 2008; Bocker ve ark., 1995). Tip II ve Tip III ekşi hamurlarda ise fermentasyonu başlatmak için adapte olmuş suşların bulunduğu kültürler kullanılır. Bu tip ekşi hamurlar çeşitli LAB ve mayaların un ve su karışımına eklenmesi ve kontrollü koşullarda fermentasyona bırakılması ile elde edilmektedir. Tip II ekşi hamur sıvı formdadır ve endüstriyel üretimlerde kullanımı daha kolay olduğu ve standart ürün üretimi sağlanabildiği için tercih edilmektedir. Tip III ekşi hamur ise ekşitilmiş hamurun kurutulması ile hazırlanmaktadır. Bu ekşi hamur tipi fırıncılık ürünlerinde aroma verici ve asitlendirici olarak kullanılmaktadır. Ayrıca Tip I ekşi hamurdan farklı olarak Tip II ve Tip III ekşi hamura kabartma ajanı olarak Saccharomyces cerevisiae ilave edilmesi gerekmektedir (Decock ve Cappelle, 2005; De Vuyst ve Neysens, 2005; Kitahara ve ark., 2005; Corsetti ve Settanni, 2007).

Unlu mamüller sektöründe önemli bir yere sahip olan ekşi hamur, firıncılık teknolojisinde ekmek, tatlı firıncılık ürünleri, kraker, atıştırmalık ürünler, pizza gibi ürünlerin üretilmesinde endüstriyel mayalara alternatif olarak kullanılmaktadır (Hansen ve Schieberle, 2005). Buğday unundan elde edilen ekşi hamur; 200'den fazla, farklı ekşi ekmek türü (INSOR, 2000) dahil olmak üzere İtalyan firıncılık ürünlerinin \%30’undan fazlasında kullanılır (Ottogalli ve ark., 1996). Ekmek üretimi haricinde, Tip I ekşi hamur kullanılarak geleneksel yöntemlerle pişirilmiş ve genellikle dini bayramlarda tüketilen bazı tatlı firıncılık ürünlerinin de olduğu görülmüştür (Foschino ve ark. 1999; Vernocchi ve ark. 2004). Bu ürünlerin çoğu bölgeseldir; fakat Panettone, Pandoro ve Colomba gibi çeşitleri ulusal statü kazanmıştır. Endüstriyel tesislerde üretilerek İtalya başta olmak üzere dünyanın pek çok yerine dağılmışlardır. Kökeni Milano’ya uzanan Panettone, ekşi hamur ile hazırlanan kek hamuruna meyve şekerlemesi ve kuru üzüm ilavesi ile hazırlanır. 19. Yüzyılda popüleritesi artarak Kuzey İtalya'ya, daha sonra göçmenler ile Kuzey ve Güney Amerika'ya taşınmıştır. Noel zamanı bu ülkelerde, Panettone pişirmek veya hazır olarak satılan keklerden alarak aileleri ile tüketmek bir gelenek haline gelmiştir. Zamanla çikolata parçalı, kakaolu, krema dolgulu çeşitleri üretilmiştir. Veronese tatlısı olarak bilinen Pandoro, Panettone'ye benzer şekilde fakat daha zengin tereyağı ve yumurta kullanılarak üretilmektedir. İçerdiği yüksek miktarda yumurtadan dolayı "altın ekmek" olarak da isimlendirilmektedir. Panettone ile arasındaki bir diğer fark ise hamur hazırlanırken kuru meyve ve şekerleme ilave edilmemesi, sade şekilde pişirilmesidir. Kekler 8 köşeli yıldız şeklinde kek kalıbında pişirilir ve bu kekin kendine has özelliğini oluşturmaktadır. $\mathrm{Bu}$ iki ünlü İtalyan Noel tatlısına benzeyen Colomba, İtalya'nın geleneksel Paskalya kekidir. "Colomba” İtalyancada güvercin anlamına gelmektedir ve kek pişirilirken güvercik şeklinde kek kalıpları kullanılır. Panettone'ye benzer şekilde kek hamuru un, yumurta, şeker, ekşi hamur ve tereyağı kullanılarak yapılır. Panettone'nin aksine meyve kabuğu şekerlemesi ve kuru üzüm kullanılmaz. Hazırlanan hamurlara güvercin şekli verilir ve pişirilmeden önce üzerlerine inci şekeri ve badem koyulur (Garofalo ve ark., 2008).

Dünya'da, özellikle İtalya'da, yüzlerce farklı türde geleneksel ekşi hamur mevcuttur. Kullanılan unun türü, orijini ve saklama koşulları, diğer malzemelerin mikrobiyotası, hijyen koşulları, uygulanan teknoloji ve fermentasyon işlemlerinde farklılıklar gözlenir. Bu farklılıklar sonucunda ekşi hamur, metabolik olarak aktif olan, un ve su eklenmesi ile yeniden etkinleştirilebilen çeşitli LAB türleri ve mayalar için önemli bir kaynaktır (De Vuyst ve Vancanneyt, 2007; Katina, 2005). Fermente gıda uygulamalarının çoğunda laktik asit bakterilerinin homofermentatif türleri kullanılmasına rağmen ekşi hamur fermentasyonunda heterofermentatif LAB türleri etkin role sahiptir. Homofermentatif laktik asit bakterileri glikoliz (homolaktik fermentasyon) ile glukozdan başlayarak laktik asit üretirken, heterofermentatif laktik asit bakterileri laktik asitin yanında $\mathrm{CO}_{2}$, asetik asit ve/veya etanol üretir (Corsetti ve Settanni, 2007). Zorunlu ve fakültatif heterofermentatif ve zorunlu homofermentatif türlerden oluşan ekşi hamur laktobasilleri tip I, tip II, tip III ekşi hamurlar ve tip 0 hamur ile ilişkilidir. Spontan şekilde gelişen Tip I ekşi hamurun mikrobiyotası başta kullanılan hammaddeler olmak üzere hijyenik koşullar, ortam ve depolama sıcaklığı, $\mathrm{pH}$, fermentasyon süresi gibi parametrelere göre değişiklik göstermektedir. Ticari starter kültürlerin kullanıldığı Tip II ve Tip III ekşi hamurlarda ise starter kültürler baskın mikrobiyatayı oluşturmaktadır. Spontan şekilde gelişmeler mikrobiyota hakimiyeti göstermez (Katina, 2005; Liang ve ark., 2016; Stolz, 2003) Fermentasyonu ekmek mayası ile sağlanan tip 0 hamur ekşi hamur teknolojisi ile üretilmemektedir (Corsetti ve Settanni, 2007). Şimdiye kadar yapılan araştırmalarla, ekşi hamurdan izole edilmiş laktik asit bakterilerinin 50'ye yakın farklı türü tespit edilmiştir. Leuconostoc (genellikle Leuconostoc mesenteroides), Weissella, Pediococcus (genellikle Pediococcus pentosaceus), Lactococcus, Enterococcus ve Streptococcus cinslerine ait türler ekşi hamurdan izole edilse de en sık gözlenen bakteriler Lactobacillus suşlarıdır. Lactobacillus sanfranciscensis, Lb. brevis, Lb. pontis, Lb. plantarum ve Lb. reuteri ekşi hamurlardan en sık izole edilen laktobasillerdir (De Vuyst ve Neysens, 2005; Corsetti ve Settanni, 2007). 
Yöresel ekşi hamurların sahip olduğu mikrobiyotaların belirlenmesi için çeşitli çalışmalar yapılmıştır. Gobbetti (1998), İtalyada yetişen buğdaylardan elde edilen ekşi hamurda Lb. sanfranciscensis / Lb. plantarum birliğinin var olduğunu bildirmiştir. Rusya'da elde edilen ekşi hamurlar incelendiğinde genellikle $L b$. brevis ve Lb. plantarum'un Lb. fermentum ile ilişkili olduğu bulunmuştur (Kazanskaya ve ark.,1983). Lactobacillus zymae hem Belçika hem de Yunan ekşi hamurundan izole edilmiştir. Coğrafi yayılım gösterdiği gözlenmesine rağmen suş sayısı her durumda tek bir izolatla sınırlandırılmıştır (De Vuyst ve ark. 2002; Vancanneyt ve ark., 2005). Türkiye'nin Doğu Karadeniz bölgesinden geleneksel Türk ekşi hamurlarına yapılan analizler sonucunda toplam 249 Laktik Asit Bakteri (LAB) izolatı bulunmuştur. Bu izolatların genotipik karakterizasyonu, 11 farklı türe ait 47 ayrı LAB suşunun varlığını ortaya çıkarmıştır: Lb. plantarum, Lb. paraplantarum, Lb. curvatus, Lb. rossiae, Lb. sanfranciscensis, Lb. brevis, Lb. paralimentarius, Weissella paramesenteroides, Leuconostoc mesenteroides, Leu. pseudomesenteroides ve Weissella cibaria. Ekşi hamur LAB mikrobiyotasının, örnek kökenine, toplama periyoduna ve heterofermentatif LAB baskınlı̆̆ına bağlı olarak farklılık gösterdiği gözlenmiştir (Dertli ve ark., 2016).

Geleneksel tatlı firıncılık ürünlerini hazırlamak için kullanılan ekşi hamurlarda gelişen mikrobiyota, kültüre bağlı teknikler kullanılarak araştırılmıştır. Galli ve Ottogalli (1973), Panettone'de yaptığı inceleme ile Lb. brevis ve Torulopsis holmii izolatlarını tanımlayarak ilk mikrobik karakterizasyonunu gerçekleştirmiştir. Ayrıca, Galli ve ark. (1988) Panettone ve tatlı çörek için kullanılan ekşi hamurlardan, Starmerella bombicola ve Saccharomyces exiguus'a ek olarak Lb. sanfranciscensis, Lb. brevis ve Leu. mesenteroides' i izole etmişlerdir.

Bu çalışmada, Tip I ekşi hamur ile üretilmiş kek hamurundaki LAB çeşitliliği incelenmiş ve bu LAB türlerinin asit üretim yetenekleri ve hızları, farklı $\mathrm{pH}$ değerlerinde gelişme ve farklı tuz konsantrasyonlarında gelişme yetenekleri ile antibakteriyel aktiviteleri belirlenmiştir.

\section{Materyal ve Metot}

Yapılan çalışmada ürün formülasyonlarında un, su, yumurta, süt, şeker, fruktoz şurubu, yağlar, kabartıcı, aroma verici, tuz ve kuru meyve çeşitleri kullanılmış ve bu hammaddeler Şölen Çikolata Gıda San. ve Tic. A.Ş. tarafından sağlanmıştır.

\subsection{Ekşi Hamur Fermentasyonu ile Kek Hamuru Üretimi}

Ekși hamur fermentasyonu ile üretilmiş kek hamurunda kullanılan Tip I ekşi hamur eldesi için 1:1 oranında un ve su karıştırılıp fermentasyon kabininde (Wiesheu $\mathrm{GmbH}$, Almanya) $25-27^{\circ} \mathrm{C}$ 'de, \%80-90 bağıl nemde 24 saat fermentasyona bırakılmıştır. Ekşi hamurun sahip olduğu özellikleri elde edebilmek için fermentasyon sonunda elde edilen hamur; 1:1 oranında un ve su ile tekrar beslenmiş ve aynı koşullarda 24 saat fermentasyona bırakılmıştır.

Ekşi hamur fermentasyonu ile üretilmiş kek hamurlarının elde edilmesi için farklı oranlarda $(\% 10, \% 15, \% 20)$ tip I ekşi hamur içeren 3 farklı kek formülasyonu oluşturulmuştur. Ekşi hamur ve formülasyonda yer alan diğer bileşenler karıştırılarak elde edilen hamurlar fermentasyon kabininde $30-35^{\circ} \mathrm{C}^{\prime}$ de, \%80-90 bağıl nemde $4-6$ saat fermentasyona bırakılmıştır.

\subsection{Laktik Asit Bakterisi (LAB) İzolasyonu}

Fermentasyon sonunda farklı oranlarda (\%10, \%15, \%20) ekşi hamur içeren kek hamurlarından laktik asit bakterilerinin izolasyonu için 10'ar gram örnek tartılmış ve üzerlerine $90 \mathrm{~mL}$ steril peptonlu su ilave edilen örnekler homojenize edilmiştir. Bu şekilde $10^{-1}$ ' lik dilüsyonlar elde edilmiş ve $10^{-8}$ ' e kadar dilüsyonlar hazırlanmıştır. Hazırlanan dilüsyonlardan MRS (Merck, Almanya) agara yayma yöntemi ile ekim yapılmış ve besiyerleri $37^{\circ} \mathrm{C}$ 'de 48 saat inkübasyona bırakılmıştır. İnkübasyon sonunda gelişen LAB'dan 18 tane farklı koloni seçilmiş ve tek koloniye düşürme yöntemi ile MRS (Merck, Almanya) agara ekim yapılarak $37^{\circ} \mathrm{C}$ 'de 48 saat inkübasyona bırakılmıştır.

\subsection{LAB Türlerinin Tanımlanması}

DNA ekstraksiyonunu gerçekleştirmek için Fenol-Kloroform Ekstraksiyon yöntemi kullanılmıştır. İzole edilen laktik asit bakterileri tek koloniye düşürme yöntemi kullanılarak MRS (Merck, Almanya) agara ekilmiş ve $37^{\circ} \mathrm{C}$ 'de 48 saat inkübasyona bırakılarak aktifleştirilmiştir. Aktif bakterilerden tek koloni alınarak $1 \mathrm{~mL}$ MRS (Merck) broth içeren mikrosantrifüj tüpüne ekim yapılmış ve $37^{\circ} \mathrm{C}$ 'de 24 saat inkübasyona bırakılmıştır. Gelişme sonrası mikrosantrifüj tüpleri 10 dakika $8000 \mathrm{rpm}$ hızda santrifüj edilmiştir. Sıvı kısım uzaklaştırılarak elde edilen peletlere $450 \mu \mathrm{L}$ TE (Tris-EDTA) tamponundan ilave edilerek karıştırılmıştır. Karışımlara \%10'luk $50 \mu \mathrm{L}$ SDS (sodyum dodesil sülfat) ve 2,5 $\mu \mathrm{L}$ proteinaz K ilave edilmiştir. Elde edilen karışımlar iyice karıştırılmış ve $37^{\circ} \mathrm{C}$ 'de 1 saat inkübe edilmiştir. İnkübasyon sonunda karışımlara fenol-kloroform karışımından $0,5 \mathrm{~mL}$ ilave edilmiş, aşağı ve yukarı yönlü çevrilerek iyice karışmaları sağlanmış ve oda sıcaklığında $5 \mathrm{dk}$ inkübe edilmiştir. Bekletilen karışımlar $4^{\circ} \mathrm{C}$ 'de 10 dakika $8000 \mathrm{rpm}$ hızda santrifüj edilmiştir. Süpernatant benzeri yüksek viskoziteli jel ve şeffaf kısım pipet ucu ile toplanmış ve yeni bir mikrosantrifüj tüpüne alınmıştır. İşlem fenol-kloroform karışımı ile bir kez daha tekrarlanmış ve süpernatantlar toplanarak yeni mikrosantrifüj tüplerine alınmış, 5M Sodyum Asetat'dan $50 \mu \mathrm{L}$ içeriğe ilave edilmiş ve hafifçe karıştırılmıştır. İzopropanoldan 1 mL ilave edilerek çöken DNA'nın beyaz iplikleri görünene kadar aşağı ve yukarı yönlü çevrilerek hafifçe karıştırılmıştır. İçerik 10 dakika $5000 \mathrm{rpm}$ hızda santrifüj edilmiştir. İşlem sonrası süpernatant kısım uzaklaştırılarak $0,5 \mathrm{~mL} \% 70$ 'lik etanol ilave edildikten sonra 10 dakika $5000 \mathrm{rpm}$ hızda santrifüj edilen karışım $37^{\circ} \mathrm{C}$ 'de $5-10 \mathrm{dk}$ kurutulmuş ve $100 \mu \mathrm{L}$ ultra saf su ilave edilerek karıştırılmıştır.

İzole edilen LAB türlerinin tanımlanması için 16S Ribozomal RNA (rRNA) Polimeraz Zincir Reaksiyonu (PZR-PCR) kurulmuştur. Primer olarak AMP-F ve AMP-R seçilmiştir. 18 DNA örneği için de Tablo 1a'da belirtilen bileşenler, belirlenen 
miktarlarda kullanılarak $25 \mu \mathrm{L}$ 'lik karışımlar elde edilmiştir. Elde edilen karışımlara belirtilen parametrelerde (Tablo 1b) termal döngü programı uygulanmıştır. DNA'lara agaroz jel elektroforez yöntemi uygulamak için 0,5 X TBE (Tris-Borat-EDTA) kullanılarak \%1'lik agaroz jel hazırlanmış ve TBE (Tris-Borat-EDTA) dolu tanka yerleştirilmiştir. Jelde bulunan kuyucuklara $1 \mu \mathrm{L}$ bromfenol mavisi ile boyanmış $4 \mu \mathrm{L}$ DNA örneği koyulmuştur. Boş kalan kuyulara pozitif, negatif ve markır koyulduktan sonra yürütme işlemi gerçekleştirilmiştir. Yürütme işlemi sonrasında jel etidyum bromür ile boyanarak görüntülenmiştir. Alınan bant görüntüsü ve DNA örnekleri; sekans analizi için dış laboratuvara (Medsantek, İstanbul, Türkiye) göderilmiştir. Filogenetik ağaç, PAUP sürüm 4.0 beta 10 kullanılarak 2000 önyükleme kopyaları ile komşu birleştirme mesafe yöntemi (neighbor-joining distance method) kullanılarak kümelenmiştir.

Tablo 1a. PZR karlşımları

\begin{tabular}{|l|c|}
\hline \multicolumn{1}{|c|}{ PZR Bileşenleri* } & Miktar \\
\hline Buffer & $2,5 \mu \mathrm{L}$ \\
\hline dNTPs & $2 \mu \mathrm{L}$ \\
\hline Primer 1 & $0,5 \mu \mathrm{L}$ \\
\hline Primer 2 & $0,5 \mu \mathrm{L}$ \\
\hline Taq polimeraz & $0,0625 \mu \mathrm{L}$ \\
\hline DNA & $0,5 \mu \mathrm{L}$ \\
\hline Ultra Saf Su & $18,9375 \mu \mathrm{L}$ \\
\hline TOPLAM & $25 \mu \mathrm{L}$ \\
\hline
\end{tabular}

*Vivantis, Malezya

\subsection{LAB İzolatlarının Asit Üretim Yeteneklerinin ve Hızlarının Belirlenmesi}

Tip I ekşi hamur fermentasyonu ile üretilmiş kek hamurlarından izole edilen LAB türleri MRS (Merck) sıvı besiyerinde $37^{\circ} \mathrm{C}^{\prime} \mathrm{de}$ 48 saat aktifleştirilmiş, $10 \mathrm{~mL}$ steril MRS sıvı besiyerine aktif kültürlerden $\% 1$ oranında 2 paralelli olarak aşılama yapılmış ve $37^{\circ} \mathrm{C}$ 'de inkübasyona bırakılmıştır. İnkübasyonun 24. ve 48. saatinde, $0,01 \mathrm{~N} \mathrm{NaOH}$ (Merck) çözeltisi ve \%1'lik fenolftalein indikatörü kullanılarak titrasyon asitliği tayini ile oluşan asit miktarı belirlenmiş̧ir. Titrasyon asitliği aşağıdaki formül kullanılarak \% laktik asit cinsinden hesaplanmıştır (Bulut, 2003).

$$
\% \text { Asitlik }=[(\mathrm{VxFxE}) / \mathrm{m}] \times 100
$$

V: Titrasyonda harcanan $\mathrm{NaOH}$ miktarı $(\mathrm{mL})$

F: Titrasyonda kullanılan bazın normalitesi

E: $1 \mathrm{~mL} \mathrm{NaOH}$ ' in eşdeğeri asit miktarı (g)

Laktik asit için E: $0,09 \mathrm{~g}$

m: Örnek miktarı $(\mathrm{mL})$

\subsection{LAB İzolatlarının Farklı pH Değerlerinde Gelişme Yeteneklerinin Belirlenmesi}

Tip I ekşi hamur fermentasyonu ile üretilmiş kek hamurlarından izole edilen LAB türleri MRS (Merck) sıvı besiyerinde $37^{\circ} \mathrm{C}$ 'de 48 saat aktifleştirilmiștir. $2 \mathrm{~N} \mathrm{NaOH}$ (Merck) ve $2 \mathrm{~N} \mathrm{HCl}$ (Merck) kullanılarak pH değerleri 2, 4 ve 9,6 olarak ayarlanan $5 \mathrm{~mL}$ 'lik MRS sıvı besiyerlerine aktif kültürlerden \%1 oranında 2 paralelli olarak ekim yapılmış ve $37^{\circ} \mathrm{C}$ 'de 48 saat inkübasyona bırakılmıştır. Gelişme miktarını belirlemek için yayma yöntemi kullanılarak MRS (Merck) agara ekim yapılmış; $37^{\circ} \mathrm{C}$ 'de 48 saat inkübasyon sonunda gelişen koloni sayıları sayılmıştır.

\subsection{LAB İzolatlarının Farklı Tuz Konsantrasyonlarında Gelişme Yeteneklerinin Belirlenmesi}

Tip I ekşi hamur fermentasyonu ile üretilmiş kek hamurlarından izole edilen LAB türleri MRS (Merck) sıvı besiyerinde $37^{\circ} \mathrm{C}$ 'de 48 saat aktifleştirilmiştir. $\mathrm{NaCl}$ eklenerek hazırlanan $\% 0, \% 3, \% 6, \% 9$ tuz konsantrasyonlarına sahip $5 \mathrm{~mL}$ 'lik MRS sıvı besiyerlerine aktif kültürlerden $\% 1$ oranında 2 paralelli ekim yapılmış ve $37^{\circ} \mathrm{C}$ 'de 7 gün inkübasyona bırakılmıştır. Gelişme miktarını belirlemek için yayma yöntemi kullanılarak MRS (Merck) agara ekim yapılmış; $37^{\circ} \mathrm{C}$ 'de 48 saat inkübasyon sonunda gelişen koloni sayıları sayılmıştır.

\subsection{Antibakteriyel Aktivitenin Belirlenmesi}

Laktik asit bakterilerinin antibakteriyel aktivitesinin belirlenmesi için agar kuyu difüzyon yöntemi kullanılmıştır.

İndikatör mikroorganizma olarak seçilen Escherichia coli ATCC 25922, Salmonella Typhimurium ATCC 0402, Bacillus cereus RSKK 963, Staphylococcus aureus ATCC 25923 tek koloniye düşürme yöntemi ile Nutrient Agar (Merck) besiyerinde $37^{\circ} \mathrm{C}$ 'de 24 saat aktifleştirilmiştir. Aktifleşen kültürlerden tek koloni alınarak $5 \mathrm{~mL}$ 'lik Nutrient Broth (Merck) bulunan tüplere ekim yapılmış ve $37^{\circ} \mathrm{C}$ 'de 5 saat inkübasyona bırakılmıştır. İzole edilen laktik asit bakteri türleri $37^{\circ} \mathrm{C}$ 'de 48 saat aktifleştirilmiştir. Aktif kültürlerden 
tek koloni alınarak $1 \mathrm{~mL}$ 'lik MRS (Merck) broth içeren ependorflara ekim yapılmış ve $37^{\circ} \mathrm{C}^{\prime}$ de 24 saat inkübasyona bırakılmıştır. İnkübasyon sonunda ependorflar santrifüj edilmiştir. İndikatör mikroorganizmaların geliştiği tüpler vortekslenmiş, kontrol ve örnekler için bölümlere ayrılmış Nutrient Agar besiyeri içeren petrilere yayma yöntemi kullanılarak ekim yapılmıştır. Belirlenen bölümlere 4 milimetrelik kuyular açılmıştır. Kontrol olarak belirlenen kuyulara $10 \mu \mathrm{L}$ steril saf su, örnekler için hazırlanan kuyulara elde edilen süpernatantlardan $10 \mu \mathrm{L}$ eklenmiştir. Petriler $37^{\circ} \mathrm{C}$ 'de 48 saat gelişmeye bırakılmıştır. Gelişme sonrası kuyuların çevresinde oluşan berrak zon çapı ölçülmüştür.

\section{8. İstatiktiksel Analiz}

Elde edilen verilen analizi ve değerlendirilmesi için JMP 6.0 programı kullanılmıştır. Veriler ortalama \pm standart sapma şeklinde ifade edilmiştir. Değerlendirilen parametrelere iki yönlü varyans analizi yapılmış ve örnekler arasındaki farklılıklar $\alpha=0,05$ önem düzeyinde LS Means Student's t testi kullanılarak harflendirilmiştir.

\section{Araştırma Sonuçları ve Tartışma}

\subsection{Bakteri Türlerinin Tanımlanması}

Sekans analizi sonucunda 10 adet Pediococcus pentosaceus (MK1, MK2, MK3, MK6, MK7, MK8, MK11, MK16, MK18, MK19), 5 adet Lactobacillus curvatus (MK4, MK5, MK13, MK17, MK20) ve 3 adet Leuconostoc mesenteroides (MK9, MK12, MK15) tanımlanmıştır (Şekil 1).

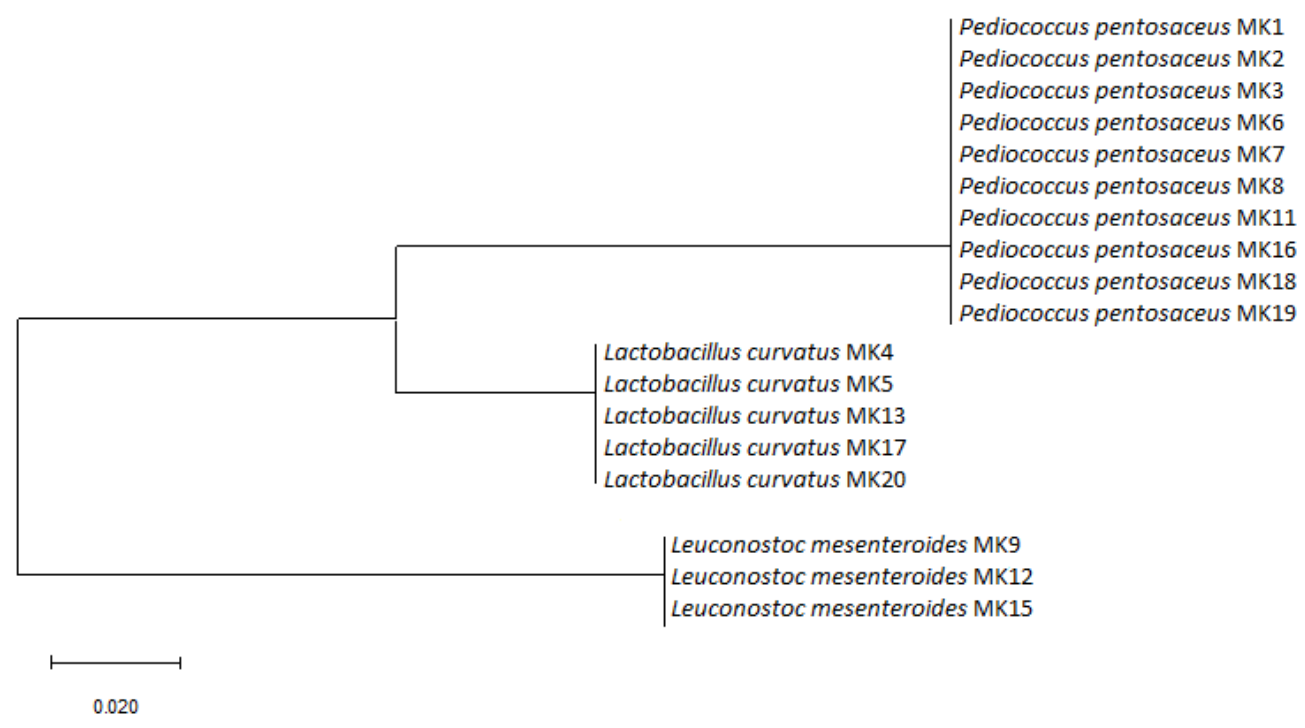

Şekil 1. Filogenetik ă̆aç

\subsection{LAB İzolatlarının Asit Üretim Yetenekleri ve Hızları}

İzole edilen LAB türlerinin asit üretim miktarları 24 ve 48 saat inkübasyon süreleri sonunda laktik asit cinsinden hesaplanmıştır (Tablo 2). 24 saat sonunda Lactobacillus curvatus (MK4) izolatının en az asit üretim miktarına sahip olduğu gözlenirken (0,459 $\pm 0,01$ $\mathrm{g} / 100 \mathrm{~mL}$ ), Pediococcus pentosaceus (MK16) izolatının en fazla asit üretim miktarına sahip olduğu tespit edilmiştir $(1,089 \pm 0,01$ g/100 mL). 48 saat sonunda yapılan analiz sonucunda Lactobacillus curvatus (MK4) izolatının en az asit üretim miktarına sahip olduğu tespit edilirken $(0,585 \pm 0,05 \mathrm{~g} / 100 \mathrm{~mL})$, Lactobacillus curvatus (MK5) izolatının en fazla asit üretim miktarına sahip olduğu gözlenmiştir $(1,809 \pm 0,03 \mathrm{~g} / 100 \mathrm{~mL})$. 
Tablo 2. Tip I ekşi hamur fermentasyonu ile üretilmiş kek hamurlarından izole edilen LAB türlerinin asit üretimi (g/100 mL)

\begin{tabular}{|c|c|c|}
\hline LAB Örnekleri & 24. saat & 48. saat \\
\hline Pediococcus pentosaceus MK1 & $0,756 \pm 0,05^{\mathrm{EFa}}$ & $0,810 \pm 0,02^{\mathrm{Ga}}$ \\
\hline Pediococcus pentosaceus MK2 & $0,666 \pm 0,00^{\mathrm{GHa}}$ & $0,792 \pm 0,04^{\mathrm{Ga}}$ \\
\hline Pediococcus pentosaceus MK3 & $0,612 \pm 0,00^{\mathrm{HIb}}$ & $0,720 \pm 0,02^{\mathrm{GHa}}$ \\
\hline Lactobacillus curvatus MK4 & $0,459 \pm 0,01^{\mathrm{Ja}}$ & $0,585 \pm 0,05^{\mathrm{Ha}}$ \\
\hline Lactobacillus curvatus MK5 & $0,702 \pm 0,02^{\mathrm{FGb}}$ & $1,809 \pm 0,03^{\mathrm{Aa}}$ \\
\hline Pediococcus pentosaceus MK6 & $0,711 \pm 0,01^{\mathrm{EFGb}}$ & $0,846 \pm 0,00^{\mathrm{Ga}}$ \\
\hline Pediococcus pentosaceus MK7 & $0,666 \pm 0,02^{\mathrm{GHa}}$ & $1,584 \pm 0,22^{\mathrm{Ba}}$ \\
\hline Pediococcus pentosaceus MK8 & $0,774 \pm 0,02^{\mathrm{Eb}}$ & $1,260 \pm 0,02^{\mathrm{CDa}}$ \\
\hline Leuconostoc mesenteroides MK9 & $1,026 \pm 0,02^{\mathrm{ABCa}}$ & $1,233 \pm 0,05^{\mathrm{CDa}}$ \\
\hline Pediococcus pentosaceus MK11 & $0,999 \pm 0,05^{\mathrm{BCb}}$ & $1,242 \pm 0,00^{\mathrm{CDa}}$ \\
\hline Leuconostoc mesenteroides MK12 & $1,062 \pm 0,02^{\mathrm{ABa}}$ & $1,296 \pm 0,02^{\mathrm{Cb}}$ \\
\hline Lactobacillus curvatus MK13 & $0,864 \pm 0,02^{\mathrm{Db}}$ & $1,026 \pm 0,02^{\mathrm{EFa}}$ \\
\hline Leuconostoc mesenteroides MK15 & $0,702 \pm 0,02^{\mathrm{FGb}}$ & $0,864 \pm 0,00^{\mathrm{FGa}}$ \\
\hline Pediococcus pentosaceus MK16 & $1,089 \pm 0,01^{\mathrm{Ab}}$ & $1,323 \pm 0,03^{\mathrm{Ca}}$ \\
\hline Lactobacillus curvatus MK17 & $0,549 \pm 0,01^{\mathrm{Ib}}$ & $1,125 \pm 0,01^{\text {DEa }}$ \\
\hline Pediococcus pentosaceus MK18 & $0,963 \pm 0,01^{\mathrm{Cb}}$ & $1,341 \pm 0,03^{\mathrm{Ca}}$ \\
\hline Pediococcus pentosaceus MK19 & $1,044 \pm 0,02^{\mathrm{ABb}}$ & $1,296 \pm 0,00^{\mathrm{Ca}}$ \\
\hline Lactobacillus curvatus MK20 & $1,044 \pm 0,02^{\mathrm{ABb}}$ & $1,287 \pm 0,03^{\mathrm{CDa}}$ \\
\hline
\end{tabular}

Farklı büyük harfler aynı saatte LAB türleri arasındaki önemli farklılığı göstermektedir. Farklı küçük harfler aynı LAB türlerinde farklı saatler arasındaki önemli farklılığı göstermektedir $(\mathrm{p}<0,05)$.

Arslankoz (2011) tarafindan turşulardan izole edilen Pediococcus pentosaceus türlerinin 24 saat inkübasyon sonunda 0,06-0,44 $\mathrm{g} / 100 \mathrm{~mL}$ ürettiği bildirilmiştir. Bulut (2003) tarafından peynirlerden izole edilen Lactobacillus türlerinin $0,6247 \mathrm{~g} / 100 \mathrm{~mL}$ laktik asit ürettiği belirtilmiştir. Herreros ve ark. (2003) tarafından İspanyol keçi peynirinden izole edilen Leu. mesenteroides türlerinin 24 saat sonunda $0,22-0,26 \mathrm{~g} / 100 \mathrm{~mL}, L b$. plantarum türlerinin 24 saat sonunda 0,19-0,21 g/100 mL, Lb. brevis türlerinin 24 saat sonunda 0,19-0,23 g/100 mL, L. casei türleri tarafından 24 saat sonunda 0,18-0,22 g/100 mL laktik asit ürettiği belirtilmiştir.

Yapılan bu çalışmada 24 saat inkübasyon sonunda Lactobacillus türlerinin 1,044-0,459 g/100 mL laktik asit ürettiği belirlenmiş ve Bulut (2003)'un sonucunun elde edilen sonuçlar aralığında olduğu gözlenmiştir. Pediococcus pentosaceus (MK1, MK2, MK3, MK6, MK7, MK8, MK11, MK16, MK18, MK19) izolatlarının 0,612-1,089 g/100 mL asit ürettiği belirlenerek Arslankoz (2011)' un sonuçlarına göre daha yüksek sonuçlar elde edilmiştir. Leu. mesenteroides (MK9, MK12, MK15) izolatlarının 24 saat sonunda ürettiği asit miktarının, Herreros ve ark. (2003) tarafından belirlenen değerlerden daha yüksek olduğu tespit edilmiştir.

\subsection{LAB İzolatlarının Farklı pH Değerlerinde Gelişme Yetenekleri}

İzole edilen LAB türlerinin pH 2, 4 ve 9,6 değerlerinde gelişme yetenekleri incelenmiştir. MK8 ve MK19 kodlu Pediococcus pentosaceus izolatlarının $\mathrm{pH}$ 2'de gelişme göstermediği, diğer LAB izolatlarının zayıf gelişme gösterdiği görülmüştür. pH 4 'te en iyi gelişmeyi Pediococcus pentosaceus (MK6)'nın gösterirken (7,86 $\pm 0,54 \mathrm{log} \mathrm{kob} / \mathrm{g}$ ), diğer bakteri türlerinin değişken gelişme

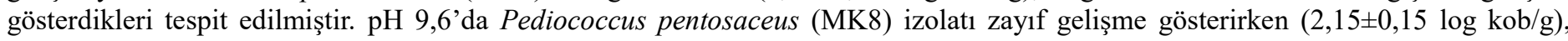
diğer bakteri izolatlarının iyi gelişme gösterdiği görülmüştür (Tablo 3). 
Tablo 3. Tip I ekşi hamur fermentasyonu ile üretilmiş kek hamurlarından izole edilen LAB türlerinin farkl pH değerlerinde gelişme saylsı (log kob/g)

\begin{tabular}{|c|c|c|c|}
\hline LAB Örnekleri & pH 2 & pH 4 & pH 9,6 \\
\hline $\begin{array}{l}\text { Pediococcus pentosaceus } \\
\text { MK1 }\end{array}$ & $7,67 \pm 0,51^{\text {Aab }}$ & $5,89 \pm 0,71^{\mathrm{CDEFGb}}$ & $9,75 \pm 0,29^{\mathrm{Aa}}$ \\
\hline $\begin{array}{l}\text { Pediococcus pentosaceus } \\
\text { MK2 }\end{array}$ & $3,77 \pm 0,02^{\mathrm{CDc}}$ & $6,41 \pm 0,01^{\mathrm{ABCDEb}}$ & $7,48 \pm 0,00^{\mathrm{BCDa}}$ \\
\hline $\begin{array}{l}\text { Pediococcus pentosaceus } \\
\text { MK3 }\end{array}$ & $3,77 \pm 0,54^{\mathrm{CDb}}$ & $7,54 \pm 0,06^{\mathrm{ABa}}$ & $6,35 \pm 0,13^{\mathrm{Da}}$ \\
\hline $\begin{array}{l}\text { Lactobacillus curvatus } \\
\text { MK4 }\end{array}$ & $4,47 \pm 0,07^{\mathrm{Aa}}$ & $5,52 \pm 0,48^{\text {DEFGa }}$ & $7,50 \pm 1,20^{\mathrm{BCDa}}$ \\
\hline $\begin{array}{l}\text { Lactobacillus curvatus } \\
\text { MK5 }\end{array}$ & $5,16 \pm 0,04^{\mathrm{Ba}}$ & $4,62 \pm 0,08^{\mathrm{FGHa}}$ & $7,94 \pm 1,76^{\mathrm{ABCDa}}$ \\
\hline $\begin{array}{l}\text { Pediococcus pentosaceus } \\
\text { MK6 }\end{array}$ & $1,67 \pm 0,18^{\mathrm{Fc}}$ & $7,86 \pm 0,54^{\mathrm{Ab}}$ & $9,95 \pm 0,25^{\mathrm{Aa}}$ \\
\hline $\begin{array}{l}\text { Pediococcus pentosaceus } \\
\text { MK7 }\end{array}$ & $4,43 \pm 0,31^{\mathrm{BCb}}$ & $4,78 \pm 0,00^{\mathrm{EFGb}}$ & $9,44 \pm 0,13^{\mathrm{Aba}}$ \\
\hline $\begin{array}{l}\text { Pediococcus pentosaceus } \\
\text { MK8 }\end{array}$ & $0,00 \pm 0,00^{\mathrm{Gc}}$ & $6,35 \pm 0,05^{\mathrm{ABCDEa}}$ & $2,15 \pm 0,15^{\mathrm{Eb}}$ \\
\hline $\begin{array}{l}\text { Leuconostoc mesenteroides } \\
\text { MK9 }\end{array}$ & $7,36 \pm 0,12^{\mathrm{Aa}}$ & $6,78 \pm 1,70^{\mathrm{ABCDa}}$ & $9,06 \pm 0,06^{\mathrm{ABCa}}$ \\
\hline $\begin{array}{l}\text { Pediococcus pentosaceus } \\
\text { MK11 }\end{array}$ & $4,39 \pm 0,01^{\mathrm{BCc}}$ & $7,43 \pm 0,02^{\mathrm{ABCb}}$ & $9,10 \pm 0,10^{\mathrm{ABa}}$ \\
\hline $\begin{array}{l}\text { Leuconostoc mesenteroides } \\
\text { MK12 }\end{array}$ & $4,28 \pm 0,43^{\mathrm{BCa}}$ & $5,92 \pm 0,52^{\mathrm{BCDEFa}}$ & $7,40 \pm 1,90^{\mathrm{CDa}}$ \\
\hline $\begin{array}{l}\text { Lactobacillus curvatus } \\
\text { MK13 }\end{array}$ & $2,75 \pm 0,02^{\mathrm{Ec}}$ & $6,42 \pm 0,01^{\mathrm{ABCDb}}$ & $8,35 \pm 0,09^{\mathrm{ABCa}}$ \\
\hline $\begin{array}{l}\text { Leuconostoc mesenteroides } \\
\text { MK15 }\end{array}$ & $1,00 \pm 0,00^{\mathrm{Fc}}$ & $4,27 \pm 0,49^{\mathrm{GHb}}$ & $8,16 \pm 0,08^{\mathrm{ABCDa}}$ \\
\hline $\begin{array}{l}\text { Pediococcus pentosaceus } \\
\text { MK16 }\end{array}$ & $3,25 \pm 0,65^{\mathrm{DEc}}$ & $5,36 \pm 0,18^{\text {DEFGb }}$ & $9,31 \pm 0,03^{\mathrm{ABa}}$ \\
\hline $\begin{array}{l}\text { Lactobacillus curvatus } \\
\text { MK17 }\end{array}$ & $3,80 \pm 0,05^{\mathrm{CDb}}$ & $4,56 \pm 0,14^{\mathrm{EFb}}$ & $8,79 \pm 0,55^{\mathrm{ABCa}}$ \\
\hline $\begin{array}{l}\text { Pediococcus pentosaceus } \\
\text { MK18 }\end{array}$ & $1,54 \pm 0,54^{\mathrm{Fc}}$ & $5,85 \pm 0,55^{\mathrm{CDEFGb}}$ & $9,27 \pm 0,09^{\mathrm{ABa}}$ \\
\hline $\begin{array}{l}\text { Pediococcus pentosaceus } \\
\text { MK19 }\end{array}$ & $0,00 \pm 0,00^{\mathrm{Gc}}$ & $4,65 \pm 0,80^{\mathrm{FGb}}$ & $9,22 \pm 0,09^{\mathrm{ABa}}$ \\
\hline $\begin{array}{l}\text { Lactobacillus curvatus } \\
\text { MK20 }\end{array}$ & $2,60 \pm 0,30^{\mathrm{Eb}}$ & $3,00 \pm 0,00^{\mathrm{Hb}}$ & $8,91 \pm 0,11^{\mathrm{ABCa}}$ \\
\hline
\end{tabular}

Farklı büyük harfler aynı pH'da LAB türleri arasındaki önemli farklılığı göstermektedir. Farklı küçük harfler aynı LAB türlerinde farklı $\mathrm{pH}$ 'lar arasındaki önemli farklılı̆̆ göstermektedir $(\mathrm{p}<0,05)$.

Tangüler (2010) tarafindan şalgam suyundan izole edilen Lactobacillus, Pediococus, Leuconostoc cinslerinin pH 4,4' de gelișme gösterdiği fakat $\mathrm{pH}$ 9,6'da hiçbir bakterinin gelişme göstermediği belirtilmiştir. Yapılan başka bir çalışmada (Kıran, 2006) hazır gıdalardan izole edilen ve çeşitli kültür koleksiyonlarından alınmış laktik asit bakterilerinin hiçbirisinin $\mathrm{pH} 2 \mathrm{ve} \mathrm{pH} 3$ değerlerinde gelişme göstermediği tespit edilmiştir. $\mathrm{pH} 4, \mathrm{pH} 5$ ve $\mathrm{pH} 6$ değerlerinde hepsi gelişme göstermiştir. $\mathrm{pH} 9,6$ değerinde Pediococcus pentosaceus türlerinin bir kısmının geliştiği bazılarının zayıf gelişme gösterdiği tespit edilirken; Lb. plantarum, Lb. brevis ve Lb. fermentum türlerinin geliştiği, Leuconostoc türlerinin zayıf gelişme gösterdiği belirtilmiştir. Bu çalışmada da $\mathrm{pH} 9,6$ değerinde Pediococcus pentosaceus (MK1, MK2, MK3, MK6, MK7, MK11, MK16, MK18, MK19) izolatlarının iyi gelişme gösterdiği, bir Pediococcus pentosaceus (MK8) izolatının zayıf gelişme gösterdiği tespit edilmiştir.

\subsection{LAB İzolatlarının Farklı Tuz Konsantrasyonlarında Gelişme Yetenekleri}

İzole edilen LAB türlerinin $\% 0, \% 3, \% 6, \% 9$ tuz konsantrasyonlarında gelişme yetenekleri incelenmiş, $\% 3$ tuz konsantrasyonunda en iyi gelişmeyi Lactobacillus curvatus (MK13) izolatının gösterdiği (7,33 $\pm 0,02 \mathrm{log} \mathrm{kob} / \mathrm{g}$ ), en az gelişmeyi

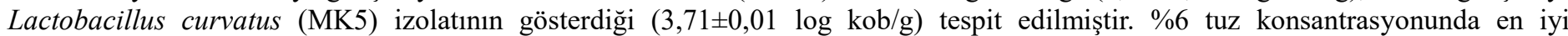

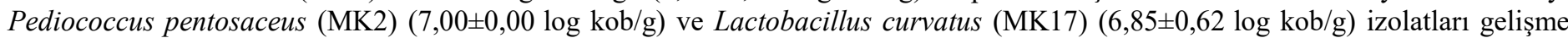
gösterirken; \%9 tuz konsantrasyonunda en iyi gelişmeyi Lactobacillus curvatus (MK17) izolatının gösterdiği (7,62 $\pm 0,21$ log kob/g) görülmüştür. \%9 tuz konsantrasyonunda En zayıf gelişmeyi ise Lactobacillus curvatus (MK20) izolatının gösterdiği tespit edilmiştir $(2,88 \pm 0,12 \log \mathrm{kob} / \mathrm{g})$ (Tablo 4). 
Tablo 4. Tip I ekşi hamur fermentasyonu ile üretilmiş kek hamurlarından izole edilen LAB türlerinin farkl NaCl değerlerinde gelişsme saylsl (log kob/g)

\begin{tabular}{|c|c|c|c|c|}
\hline LAB Örnekleri & $\% 0 \mathrm{NaCl}$ & $\% 3 \mathrm{NaCl}$ & $\% 6 \mathrm{NaCl}$ & $\% 9 \mathrm{NaCl}$ \\
\hline $\begin{array}{l}\text { Pediococcus } \\
\text { pentosaceus } \mathrm{MK} 1\end{array}$ & $5,06 \pm 0,06^{\mathrm{CDEFa}}$ & $4,63 \pm 0,03^{\text {DEb }}$ & $4,15 \pm 0,15^{\mathrm{BCDc}}$ & $5,00 \pm 0,00^{\mathrm{EFa}}$ \\
\hline $\begin{array}{l}\text { Pediococcus } \\
\text { pentosaceus } \mathrm{MK} 2\end{array}$ & $5,65 \pm 0,35^{\text {ABCDEab }}$ & $4,69 \pm 0,69^{\mathrm{DEb}}$ & $7,00 \pm 0,00^{\mathrm{Aa}}$ & $6,41 \pm 0,22^{\mathrm{BCa}}$ \\
\hline $\begin{array}{l}\text { Pediococcus } \\
\text { pentosaceus } \text { MK3 }\end{array}$ & $6,01 \pm 0,32^{\mathrm{ABCDEa}}$ & $4,95 \pm 0,05^{\mathrm{CDEa}}$ & $5,80 \pm 0,65^{\mathrm{ABCa}}$ & $6,26 \pm 0,96^{\mathrm{BCa}}$ \\
\hline $\begin{array}{l}\text { Lactobacillus } \\
\text { curvatus MK4 }\end{array}$ & $5,52 \pm 0,07^{\mathrm{ABCDEab}}$ & $4,64 \pm 0,18^{\mathrm{DEb}}$ & $5,40 \pm 1,03^{\mathrm{ABCDb}}$ & $6,46 \pm 0,69^{\mathrm{BCa}}$ \\
\hline $\begin{array}{l}\text { Lactobacillus } \\
\text { curvatus MK5 }\end{array}$ & $3,75 \pm 0,15^{\mathrm{Fb}}$ & $3,71 \pm 0,01^{\mathrm{Eb}}$ & $3,43 \pm 0,11^{\mathrm{CDb}}$ & $4,97 \pm 0,27^{\mathrm{EFa}}$ \\
\hline $\begin{array}{l}\text { Pediococcus } \\
\text { pentosaceus } \text { MK6 }\end{array}$ & $4,73 \pm 0,12^{\mathrm{DEFb}}$ & $6,31 \pm 0,35^{\mathrm{ABCab}}$ & $6,00 \pm 0,70^{\mathrm{ABab}}$ & $6,42 \pm 0,17^{\mathrm{BCa}}$ \\
\hline $\begin{array}{l}\text { Pediococcus } \\
\text { pentosaceus } \text { MK7 }\end{array}$ & $6,69 \pm 0,21^{\mathrm{ABCa}}$ & $6,65 \pm 0,35^{\mathrm{ABa}}$ & $5,72 \pm 0,02^{\mathrm{ABCb}}$ & $5,15 \pm 0,15^{\mathrm{DEFb}}$ \\
\hline $\begin{array}{l}\text { Pediococcus } \\
\text { pentosaceus } \text { MK8 }\end{array}$ & $7,04 \pm 0,04^{\mathrm{Aa}}$ & $5,95 \pm 0,35^{\mathrm{ABCDb}}$ & $4,87 \pm 0,17^{\mathrm{ABCDc}}$ & $4,85 \pm 0,15^{\mathrm{EFc}}$ \\
\hline $\begin{array}{l}\text { Leuconostoc } \\
\text { mesenteroides MK9 }\end{array}$ & $6,34 \pm 1,86^{\mathrm{ABCDa}}$ & $6,95 \pm 0,05^{\mathrm{ABa}}$ & $6,06 \pm 2,64^{\mathrm{ABa}}$ & $7,06 \pm 0,36^{\mathrm{ABa}}$ \\
\hline $\begin{array}{l}\text { Pediococcus } \\
\text { pentosaceus } \text { MK11 }\end{array}$ & $5,00 \pm 0,00^{\mathrm{CDEFa}}$ & $5,59 \pm 1,31^{\mathrm{BCDa}}$ & $3,18 \pm 0,80^{\mathrm{Da}}$ & $4,69 \pm 0,02^{\mathrm{Fa}}$ \\
\hline $\begin{array}{l}\text { Leuconostoc } \\
\text { mesenteroides MK12 }\end{array}$ & $5,19 \pm 0,19^{\mathrm{BCDEFa}}$ & $5,15 \pm 0,15^{\mathrm{CDa}}$ & $5,26 \pm 0,78^{\mathrm{ABCDa}}$ & $4,50 \pm 0,50^{\mathrm{Fa}}$ \\
\hline $\begin{array}{l}\text { Lactobacillus } \\
\text { curvatus MK13 }\end{array}$ & $3,75 \pm 1,45^{\mathrm{Fa}}$ & $7,33 \pm 0,02^{\mathrm{Aa}}$ & $4,86 \pm 1,62^{\mathrm{ABCDa}}$ & $4,26 \pm 0,04^{\mathrm{FGa}}$ \\
\hline $\begin{array}{l}\text { Leuconostoc } \\
\text { mesenteroides MK15 }\end{array}$ & $6,72 \pm 0,15^{\mathrm{ABCab}}$ & $6,93 \pm 0,47^{\mathrm{ABa}}$ & $5,93 \pm 0,03^{\mathrm{ABb}}$ & $4,62 \pm 0,12^{\mathrm{Fc}}$ \\
\hline $\begin{array}{l}\text { Pediococcus } \\
\text { pentosaceus } \text { MK16 }\end{array}$ & $6,84 \pm 0,06^{\mathrm{ABa}}$ & $4,65 \pm 0,05^{\mathrm{DEc}}$ & $5,87 \pm 0,27^{\mathrm{ABCb}}$ & $3,24 \pm 0,24^{\mathrm{GHd}}$ \\
\hline $\begin{array}{l}\text { Lactobacillus } \\
\text { curvatus } \text { MK17 }\end{array}$ & $7,11 \pm 0,33^{\mathrm{Aa}}$ & $5,97 \pm 0,43^{\mathrm{ABCDa}}$ & $6,85 \pm 0,62^{\mathrm{Aa}}$ & $7,62 \pm 0,21^{\mathrm{Aa}}$ \\
\hline $\begin{array}{l}\text { Pediococcus } \\
\text { pentosaceus } \text { MK1 } 8\end{array}$ & $4,48 \pm 0,00^{\mathrm{EFa}}$ & $4,93 \pm 0,92^{\text {CЕa }}$ & $5,89 \pm 0,15^{\mathrm{ABCa}}$ & $5,81 \pm 0,01^{\mathrm{CDEa}}$ \\
\hline $\begin{array}{l}\text { Pediococcus } \\
\text { pentosaceus } \text { MK19 }\end{array}$ & $6,45 \pm 0,15^{\mathrm{ABCDa}}$ & $5,15 \pm 0,15^{\mathrm{CDb}}$ & $6,74 \pm 0,26^{\mathrm{Aa}}$ & $6,03 \pm 0,18^{\mathrm{BCDa}}$ \\
\hline $\begin{array}{l}\text { Lactobacillus } \\
\text { curvatus MK20 }\end{array}$ & $5,04 \pm 0,04^{\mathrm{CDEFa}}$ & $4,65 \pm 0,05^{\text {DEb }}$ & $4,23 \pm 0,06^{\mathrm{BCDc}}$ & $2,88 \pm 0,12^{\mathrm{Hd}}$ \\
\hline
\end{tabular}

Farklı büyük harfler aynı $\mathrm{NaCl}$ oranında LAB türleri arasındaki önemli farklılığı göstermektedir. Farklı küçük harfler aynı LAB türlerinde farklı $\mathrm{NaCl}$ oranları arasındaki önemli farklılığı göstermektedir. $(\mathrm{p}<0,05)$

Yapılan bir çalışmada (Kıran, 2006) hazır gıdalardan izole edilen ve çeşitli kültür koleksiyonlarından alınmış laktik asit bakterilerinin \%4 tuz konsantrasyonunda tümünün gelişme gösterdiği, \%6,5 tuz konsantrasyonunda 5 tanesi hariç diğer bakterilerin gelişme gösterdiği, \%12 tuz konsantrasyonunda 4 tanesinin zayıf gelişme gösterdiği diğerlerinin gelişmediği, \%18 tuz konsantrasyonunda ise hiçbirisinin gelişme göstermediği belirtilmiştir. Bulut (2003) tarafindan yapılan bir çalışmada, \%6,5 tuz konsantrasyonunda 9 tane Lactobacillus türünün gelişme gösterdiği belirtilmiştir. Arslankoz (2011) tarafindan turşulardan izole edilen tüm bakterilerin $\% 3$ tuz konsantrasyonunda gelişme gösterdiği, $\% 3$ ve $\% 6,5$ tuz en konsantrasyonunda iyi gelişmenin Lb. plantarum'a ait olduğu; \%10 tuz konsantrasyonunda en iyi P. ethanolidurans ve Lb. plantarum türlerinin gösterdiği bildirilmiştir.

\subsection{LAB İzolatlarının Antibakteriyel Aktiviteleri}

İzole edilen LAB türlerinin indikatör mikroorganizma olarak seçilen Escherichia coli ATCC 25922, Salmonella Typhimurium ATCC 0402, Bacillus cereus RSKK 963, Staphylococcus aureus ATCC 25923'a karşı oluşturduğu zon çapları Tablo 5'te gösterilmiştir. Beş (5) mm'den küçük zon çapına sahip LAB türlerinin antibakteriyel aktiviteye sahip olmadığı kabul edilmiştir. İzole edilen LAB türlerinin seçilen 4 indikatör ve patojen bakteri üzerinde antibakteriyel aktiviteye sahip olduğu fakat Salmonella Typhimurium'a karşı oluşturdukları zon çaplarının diğer indikatör mikroorganizmalara karşı oluşturduklarından daha büyük olduğu

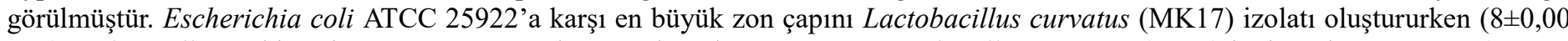

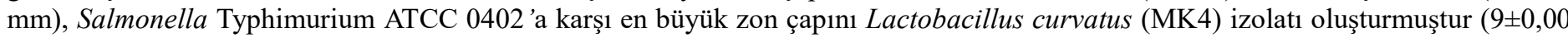
mm). LAB izolatlarının Bacillus cereus RSKK 963 ve Staphylococcus aureus ATCC 25923'a karşı oluşturdukları zon çapları değişkenlik göstermektedir. 
Tablo 5. Tip I ekşi hamur fermentasyonu ile üretilmiş kek hamurlarından izole edilen LAB türlerinin farkl mikroorganizmalar üzerindeki antibakteriyel aktivitesi sonucu oluşan zon çapları (mm)

\begin{tabular}{|c|c|c|c|c|}
\hline LAB Örnekleri & $\begin{array}{l}\text { Escherichia coli } \\
\text { ATCC } 25922\end{array}$ & $\begin{array}{l}\text { Bacillus cereus } \\
\text { RSKK } 963\end{array}$ & $\begin{array}{c}\text { Staphylococcus aureus } \\
\text { ATCC } 25923\end{array}$ & $\begin{array}{c}\text { Salmonella } \\
\text { Typhimurium } \\
\text { ATCC } 0402 \\
\end{array}$ \\
\hline $\begin{array}{c}\text { Pediococcus } \\
\text { pentosaceus } \text { MK1 }\end{array}$ & $6,5 \pm 0,05^{\mathrm{ABa}}$ & $6,0 \pm 0,00^{\mathrm{ABa}}$ & $6,0 \pm 0,00^{\mathrm{Aa}}$ & $5,5 \pm 0,05^{\mathrm{Ca}}$ \\
\hline $\begin{array}{c}\text { Pediococcus } \\
\text { pentosaceus } \text { MK2 }\end{array}$ & $6,0 \pm 0,00^{\mathrm{ABa}}$ & $5,5 \pm 0,05^{\mathrm{ABa}}$ & $6,0 \pm 0,00^{\mathrm{Aa}}$ & $7,0 \pm 0,10^{\mathrm{ABCa}}$ \\
\hline $\begin{array}{c}\text { Pediococcus } \\
\text { pentosaceus } \text { MK3 }\end{array}$ & $5,5 \pm 0,05^{\mathrm{Ba}}$ & $6,0 \pm 0,00^{\mathrm{ABa}}$ & $6,0 \pm 0,00^{\mathrm{Aa}}$ & $7,0 \pm 0,10^{\mathrm{ABCa}}$ \\
\hline $\begin{array}{l}\text { Lactobacillus } \\
\text { curvatus MK4 }\end{array}$ & $6,5 \pm 0,05^{\mathrm{ABab}}$ & $7,0 \pm 0,10^{\text {Aab }}$ & $6,0 \pm 0,00^{\mathrm{Ab}}$ & $9,0 \pm 0,10^{\mathrm{Aa}}$ \\
\hline $\begin{array}{l}\text { Lactobacillus } \\
\text { curvatus MK5 }\end{array}$ & $5,5 \pm 0,05^{\mathrm{Ba}}$ & $6,0 \pm 0,00^{\mathrm{ABa}}$ & $6,0 \pm 0,00^{\mathrm{Aa}}$ & $6,0 \pm 0,00^{\mathrm{BCa}}$ \\
\hline $\begin{array}{c}\text { Pediococcus } \\
\text { pentosaceus } \text { MK6 }\end{array}$ & $7,0 \pm 0,10^{\mathrm{ABab}}$ & $6,0 \pm 0,00^{\mathrm{ABb}}$ & $6,0 \pm 0,00^{\mathrm{Ab}}$ & $8,0 \pm 0,00^{\mathrm{ABa}}$ \\
\hline $\begin{array}{c}\text { Pediococcus } \\
\text { pentosaceus } \text { MK7 }\end{array}$ & $7,0 \pm 0,10^{\mathrm{ABa}}$ & $6,0 \pm 0,00^{\mathrm{ABa}}$ & $6,0 \pm 0,00^{\mathrm{Aa}}$ & $7,0 \pm 0,10^{\mathrm{ABCa}}$ \\
\hline $\begin{array}{c}\text { Pediococcus } \\
\text { pentosaceus } \text { MK8 }\end{array}$ & $7,0 \pm 0,10^{\mathrm{ABa}}$ & $5,0 \pm 0,00^{\mathrm{Ba}}$ & $6,0 \pm 0,00^{\mathrm{Aa}}$ & $7,0 \pm 0,10^{\mathrm{ABCa}}$ \\
\hline $\begin{array}{c}\text { Leuconostoc } \\
\text { mesenteroides MK9 }\end{array}$ & $7,0 \pm 0,10^{\mathrm{ABa}}$ & $6,0 \pm 0,00^{\mathrm{ABab}}$ & $5,0 \pm 0,00^{\mathrm{Bb}}$ & $6,0 \pm 0,00^{\mathrm{BCab}}$ \\
\hline $\begin{array}{c}\text { Pediococcus } \\
\text { pentosaceus } \mathrm{MK} 11\end{array}$ & $7,0 \pm 0,10^{\mathrm{ABab}}$ & $6,0 \pm 0,00^{\mathrm{ABb}}$ & $6,0 \pm 0,00^{\mathrm{Ab}}$ & $8,0 \pm 0,00^{\mathrm{ABa}}$ \\
\hline $\begin{array}{c}\text { Leuconostoc } \\
\text { mesenteroides } \mathrm{MK} 12\end{array}$ & $5,5 \pm 0,05^{\mathrm{Ba}}$ & $7,0 \pm 0,10^{\mathrm{Aa}}$ & $5,5 \pm 0,05^{\mathrm{ABa}}$ & $7,0 \pm 0,10^{\mathrm{ABCa}}$ \\
\hline $\begin{array}{c}\text { Lactobacillus } \\
\text { curvatus MK13 }\end{array}$ & $6,0 \pm 0,00^{\mathrm{ABa}}$ & $7,0 \pm 0,10^{\mathrm{Aa}}$ & $5,5 \pm 0,05^{\mathrm{ABa}}$ & $6,0 \pm 0,00^{\mathrm{BCa}}$ \\
\hline $\begin{array}{c}\text { Leuconostoc } \\
\text { mesenteroides MK15 }\end{array}$ & $7,0 \pm 0,10^{\mathrm{ABa}}$ & $6,0 \pm 0,00^{\mathrm{ABa}}$ & $5,5 \pm 0,05^{\mathrm{ABa}}$ & $6,0 \pm 0,00^{\mathrm{BCa}}$ \\
\hline $\begin{array}{c}\text { Pediococcus } \\
\text { pentosaceus } \text { MK16 }\end{array}$ & $5,5 \pm 0,05^{\mathrm{Ba}}$ & $7,0 \pm 0,10^{\mathrm{Aa}}$ & $5,0 \pm 0,00^{\mathrm{Ba}}$ & $7,0 \pm 0,10^{\mathrm{ABCa}}$ \\
\hline $\begin{array}{c}\text { Lactobacillus } \\
\text { curvatus MK17 }\end{array}$ & $8,0 \pm 0,00^{\mathrm{Aa}}$ & $6,0 \pm 0,00^{\mathrm{ABc}}$ & $5,0 \pm 0,00^{\mathrm{Bd}}$ & $6,0 \pm 0,00^{\mathrm{BCb}}$ \\
\hline $\begin{array}{c}\text { Pediococcus } \\
\text { pentosaceus } \text { MK18 }\end{array}$ & $7,0 \pm 0,10^{\mathrm{ABa}}$ & $6,0 \pm 0,00^{\mathrm{ABa}}$ & $6,0 \pm 0,00^{\mathrm{Aa}}$ & $7,0 \pm 0,10^{\mathrm{ABCa}}$ \\
\hline $\begin{array}{c}\text { Pediococcus } \\
\text { pentosaceus } \text { MK19 }\end{array}$ & $6,0 \pm 0,00^{\mathrm{ABa}}$ & $5,5 \pm 0,05^{\mathrm{ABab}}$ & $5,0 \pm 0,00^{\mathrm{Bb}}$ & $6,0 \pm 0,00^{\mathrm{BCa}}$ \\
\hline $\begin{array}{c}\text { Lactobacillus } \\
\text { curvatus } \text { MK20 }\end{array}$ & $7,0 \pm 0,10^{\mathrm{ABab}}$ & $7,0 \pm 0,10^{\mathrm{Aab}}$ & $5,0 \pm 0,00^{\mathrm{Bb}}$ & $8,0 \pm 0,00^{\mathrm{ABa}}$ \\
\hline
\end{tabular}

Farklı büyük harfler aynı mikroorganizmada LAB türleri arasındaki önemli farklılığı göstermektedir. Farklı küçük harfler aynı LAB türlerinde farklı mikroorganizmalar arasındaki önemli farklılığı göstermektedir $(\mathrm{p}<0,05)$.

Erdoğrul ve ark. (2002) yaptıkları bir çalışmada fermente sucuklardan 4 adet $P$. pentosaceus türü izole etmiş ve Bacillus megaterium, Bacillus subtilis, Micrococcus luteus, Mycobacterium smegmatus, Staphylococcus aureus, Yersinia enterocolitica üzerine antimikrobiyal etkilerini araştırmıştır. İzole edilen suşlardan sadece birinin Staphylococcus aureus'a karşı 10 mm'lik zon oluşturduğunu bildirmiştir. $\mathrm{Bu}$ çalışmada Pediococcus pentosaceus türlerinin 4 indikatör mikroorganizmaya karşı 5,0-8,0 mm büyüklüğünde zon oluşturduğu belirlenmiştir. Bir diğer çalışmada (Arslankoz, 2011) turşulardan izole edilen Pediococcus izolatlarının Listeria inocua, E. coli ve Salmonella sp.'a karş1 $10 \mathrm{~mm}$ ve 10 mm'den büyük zonlar oluşturduğu $B$. cereus, Lb. brevis'e karşı 10 mm'den küçük zonlar oluşturduğu bildirilmiştir.

\section{Sonuç}

Bu çalışmada Tip I ekşi hamur ile elde edilmiş kek hamurunun laktik asit bakteri (LAB) çeşitliliği belirlenmiş ve izole edilen LAB türlerinin teknolojik özellikleri incelenmiştir. Bu maksatla, farklı oranlarda (\%10, \%15 ve \%20) Tip I ekşi hamur kullanılarak üç farlı formulasyonda kek hamuru elde edilmiş ve 30-35 ${ }^{\circ} \mathrm{C}$ ' de, \%80-90 bağıl nemde 4-6 saat fermentasyona bırakılmıştır. Fermente kek hamurlarından laktik asit bakterileri izole edilip (farklı morfolojiye sahip kolonilerden) 16S rRNA tekniği ile tür bazında tanımlama yapilmıştır.

İzolasyonu yapılan LAB'lerin Pediococcus, Lactobacillus ve Leuconostoc cinslerine ait türler oldukları belirlenmiştir. Toplam 18 adet izolatın 10'u Pediococcus pentosaceus, 5'i Lactobacillus curvatus ve 3'ü Leuconostoc mesenteroides olarak tanımlanmışlardır. 
Tanımlanan LAB türlerinin asit üretim yeteneği, farklı pH değerlerinde gelişme, farklı tuz konsantrasyonlarında gelişme ve Escherichia coli, Salmonella Typhimurium, Bacillus cereus, Staphylococcus aureus'a karşı antibakteriyel aktivitesi belirlenmiş̧tir.

İzolatların çoğunun pH 2 'de zayıf gelişme gösterdiği ve Pediococcus izolatlarının bazılarının gelişme göstermediği; pH 9,6'da ise bir Pediococcus pentosaceus izolatı hariç diğer LAB izolatlarının iyi gelişme gösterdiği tespit edilmiştir. LAB izolatları \%9 tuz konsantrasyonunda en zayıf gelişmeyi gösterirken; \%6 tuz konsantrasyonunda en iyi gelişmeyi Pediococcus pentosaceus izolatları göstermiştir. LAB izolatlarının en yüksek antibakteriyel etkiyi Salmonella Typhimurium’a karşı gösterdikleri tespit edilmiş̧ir.

Ekmek üretimi için üretilen ekşi hamurlarda daha çok, özellikle Lb. plantarum, Lb. fermentum ve Lb. brevis gibi Lactobacillus cinsine ait türler baskın türler olarak tespit edilirken, kek ekşi hamurunda Pediococcus pentosaceus türünün öne çıtığı belirlenmiştir.

\section{Teşekkür}

Bu çalı̧̧ma Şölen Çikolata Gıda San. ve Tic. A.Ş.'nin TÜBİTAK TEYDEB tarafindan desteklenen 3180282 nolu projesi kapsamında gerçekleştirilmiştir.

\section{Kaynakça}

Arslankoz, N. (2011). Ankara Çubuk yöresi turşularından izole edilen laktik asit bakterilerinin bazı teknolojik ve fonksiyonel özelliklerinin belirlenmesi. Ankara Üniversitesi Fen Bilimleri Enstitüsü Yüksek Lisans Tezi, 71 sayfa.

Bocker, G., Stolz, P. \& Hammes, W. P. (1995). Neue erkenntnisse zum okosystem sauerteig und zur physiologie des sauerteigtypischen stamme Lactobacillus sanfrancisco und Lactobacillus pontis. Getreide Mehl und Brot, 49, 370-74.

Bulut, Ç. (2003). Isolation and molecular characterization of lactic acid bacteria from cheese. İzmir Teknoloji Enstitüsü Yüksek Lisans Tezi, 102 sayfa.

Chavan, R.S. \& Chavan, S.R. (2011). "Sourdough technology-A traditional way for wholesome foods: A review". Comprehensive Reviews in Food Science and Food Safety, 10, 169-182.

Corsetti, A. \& Settanni, L. (2007). Lactobacilli in sourdough fermentation. Food Research International, 40, 539-558.

Çağlıyan, B. İ. (2008). İzmir piyasasında satılan bazı ekmek çeşitlerinin nitelikleri ve yapım teknikleri. Ege Üniversitesi Fen Bilimleri Enstitüsü Doktora Tezi. 133 sayfa.

Decock, P. \& Cappelle, S. (2005). Bread technology and sourdough technology. Trends in Food Science \& Technology, 16, 113-120.

Dertli, E., Mercan E., Arıcı, M., Yılmaz, M.T. \& Sağdıç, O. (2016). Characterisation of lactic acid bacteria from Turkish sourdough and determination of their exopolysaccharide (EPS) production characteristics. LWT- Food Science and Technology, 71, 116-124.

De Vuyst, L., Schrijvers, V., Paramithiotis, S., Hoste, B., Vancanneyt, M., Swings, J., Kalantzopoulos, G., Tsakalidou, E. \& Messens, W. (2002). The biodiversity of lactic acid bacteria in Greek traditional wheat sourdoughs is reflected in both composition and metabolite formation. Appl. Environ. Microbiol. 68, 6059-6069.

De Vuyst, L. \& Neysens, P. (2005). The sourdough microflora: biodiversity and metabolic interactions. Trends Food Science Technology, 16, 43-56.

De Vuyst, L. \& Vancanneyt, M. (2007). Biodiversity and identification of sourdough lactic acid bacteria, Food Microbiology, 24,120127.

Elgün, A. \& Ertugay, Z. (2002). Tahıl İşleme Teknolojisi, Erzurum: Atatürk Üniversitesi Yayınları.

Erdoğrul, Ö.T., Çetin, Ö. \& Ergün, Ö. (2002). Fermente sucuklardan izole edilen Pediococcus pentosaceus suşlarının bazı metabolik ve antimikrobiyel aktiviteleri üzerine çalışmalar. İ.Ü. Veteriner Fakültesi Dergisi, 28, $249-254$.

Foschino, R., Terranno, R., Mora, D. \& Galli, A. (1999). Microbial characterization of sourdoughs for sweet baked products. Italian Journal of Food Science, 11, 19-28.

Galli, A. \& Ottogalli, G. (1973). Aspetti della microflora degli impasti per panettone. Annali di Microbiologia e Enzimologia, 23, 3949.

Galli A., Franzetti L. \& Fortina M.G. (1988). Isolation and identification of sourdough microflora. Microbiologie-Aliments-Nutrition, $6,345-351$.

Garofalo, C., Silvestri, G., Aquilanti, L. \& Clementi, F. (2008). PCR-DGGE analysis of lactic acid bacteria and yeast Dynamics during the production processes of three varieties of Panettone. Journal of Applied Microbiology, 105, 243-254.

Gobbetti, M. (1998). The sourdough microflora: interactions of lactic acid bacteria and yeasts. Trends in Food Science and Technology, 9, 267-274.

Hansen, A. \& Schieberle, P. (2005). Generation of aroma compounds during sourdough fermentation: applied and fundamental aspects. Trends in Food Science and Technology, 16, 85-94.

Herreros, M.A., Fresno, J.M., González -Prieto, M.J. \& Tornadijo, M.E. (2003). Technological characterization of lactic acid bacteria isolated from Armada cheese (spanish goat's milk cheese). International Dairy Journal, 13, 469-479.

Istituto Nazionale di Sociologia Rurale (INSOR) (2000). Atlante dei prodotti tipici: il pane. In: F. Angeli (Ed.), Roma, Agra RAI-ERI.

Katina, K. (2005). Sourdough: A tool for the improved flavour, texture and shelf-life of wheat bread. VTT Publications 569.

Kazanskaya, L. N., Afanasyeva, O. V., \& Patt, V. A. (1983). Microflora of rye sours and some specific features of its accumulation in bread baking plants of the USSR. In J. Holas, \& F. Kratochvil, Developments in food science. Progress in cereal chemistry and technology, 5B ,759-763. London: Elsevier

Kıran, F. (2006). Hücre duvarı protein profilleri ve pilazmid içeriklerine göre laktik asit bakterilerinin moleküler tanısı. Ankara Üniveristesi Yüksek Lisans Tezi. 130 sayfa.

e-ISSN: 2148-2683 
Kitahara, M., Sakata, S. \& Benno, Y. (2005). Biodiversity of Lactobacillus sanfranciscensis isolated from five sourdoughs. Letters in Applied Microbiology, 40, 353-357.

Liang, C. Sarabani, Z. \& Berenjian, A. (2016). An overview on the health benefits and production of fermented functional foods. Journal of Advanced Medical Sciences and Applied Technologies (JAMSAT), 2 (2), 224-233.

Meroth, C. B., Walter, J., Hertel, C., Brandt, M. J. \& Hammes, W. P. (2003). Monitoring the bacterial population dynamics in sourdough fermentation processes by using PCR-denaturing gradient gel electrophoresis. Applied and Environmental Microbiology, 69, 475-482.

Minervini, F., De Angelis, M., Di Cagno R. \& Gobbetti, M. (2014). Ecological parameters influencing microbial diversity and stability of traditional sourdough. International Journal of Food Microbiology, 171, 136-146.

Ottogalli, G., Galli, A. \& Foschino, R. (1996). Italian bakery products obtained with sour dough: characterization of the typical microflora. Advances in Food Science, 18, 131-144.

Stolz, P. (2003). Biological fundamentals of yeast and Lactobacilli fermentation in bread dough. In: Handbook of Dough Fermentations, K. Kulp and K. Lorenz (Eds.), Marcel Dekker, New York, 23-43.

Tangüler, H. (2010). Şalgam suyu üretiminde etkili olan laktik asit bakterilerinin belirlenmesi ve şalgam suyu üretim tekniğinin geliştirilmesi. Çukurova Üniversitesi Fen Bilimleri Enstitüsü Doktora Tezi. 367 sayfa.

Vancanneyt, M., Neysens, P., Dewachter, M., Engelbeen, K., Snauwaert, C., Cleenwerck, I., Van der Meulen, R., Hoste, B., Tsakalidou, E., De Vuyst, L. \& Swings, J., (2005). Lactobacillus acidifarinae sp. nov. and Lactobacillus zymae sp. nov., from wheat sourdoughs. International Journal of Systematic and Evolutionary Microbiology, 55, 615-620.

Vernocchi, P., Valmorri, S., Gatto, V., Torriani, S., Gianotti, A., Suzzi, G., Guerzoni, M.E. \& Gardini, F. (2004). A survey on yeast microbiota associated with an Italian traditional sweet-leavened baked good fermentation. Food Research International, 37, 469476. 